\title{
Hubungan Antara Kepercayaan Pelanggan Dengan Loyalitas Pelanggan Terhadap Online Shop
}

\section{Correlation Between Customer Trust With Customer Loyalty Of Online Shop}

\author{
Mulia Siregar* \\ Fakultas Psikologi, Universitas Medan Area, Indonesia
}

Disubmit: 11 Maret 2021; Diproses: 16 Maret 2021; Diaccept: 01 April 2021; Dipublish: 05 April 2021

*Corresponding author: E-mail: mulia@uma.ac.id

\begin{abstract}
Abstrak
Penelitian ini bertujuan untuk melihat hubungan antara kepercayaan pelanggan dengan loyalitas pelanggan terhadap online shop pada Mahasiswa Psikologi Regular A Stambuk 2017 Universitas Medan Area. Metode yang digunakan dalam penelitian ini adalah metode kuantitatif. Subjek penelitian ini adalah mahasiswa Psikologi regular A stambuk 20017 Universitas Medan Area dengan jumlah 185 orang, namun setelah dilakukan screening dengan sistem ty out terpakai terhadap subjek, maka terdapat 50 orang mahasiswa yang sering melakukan pembelian secara online shop dan dinyatakan sebagai sampel yang sesuai dengan penelitian ini. Penelitian ini menggunakan Skala kepercayaan pelanggan (Priansa, 2018) yang terdiri dari 3 aspek yaitu kemampuan (ability), kebaikan hati (benevolence), dan Integritas (integrity). Penelitian ini menggunakan Skala Loyalitas Pelanggan yang terdiri dari 4 aspek yaitu melakukan pembelian secara teratur, membeli diluar lini produk/jasa, merekomendasikan produk/jasa kepada orang lain, dan tidak mudah terpengaruh oleh tarikan pesaing. Pengumpulan data dilakukan dengan menggunakan skala Likert dengan jumlah aitem sebanyak 57 aitem. Nilai validitas aitem dalam penelitian ini adalah 0,921 dan 0,929 yang ukur menggunakan Alpha Cronbach's. Berdaasarkan analisis dengan menggunakan Pearson Product Moment maka diperoleh hasil bahwa terdapat hubungan positif yang signifikan antara Kepercayaan Pelanggan dengan Loyalitas Pelanggan, dimana $\mathrm{r}_{\mathrm{xy}}=0,459$ dengan signifikan $\mathrm{p}=0.001<0.050$. Dan menunjukkan hasil analisis persentase sebesar 21,1\%. Maka dapat disimpulkan bahwa hipotesis yang diajukan dinyatakan diterima dengan hasil ada hubungan antara Kepercayaan Pelanggan dengan Loyalitas Pelanggan.
\end{abstract}

Kata Kunci: Kepercayaan Pelanggan; Loyalitas Pelanggan

\begin{abstract}
This study aims to see the correlation between customer trust with customer loyalty of online shop at class of Regular A Psychology Students 2017 Medan Area University. The method used in this research is quantitative method. The subjects of this study were Regular A Psychology Students 2017 Medan Area University.with a total of 185 people, but after screening with the ty out system used for the subject, there were 50 students who often made online shop purchases and were declared as samples in accordance with this study. This research uses customer trust scale (Priansa, 2018) which consists of 3 aspects, namely ability, benevolence, and integrity. This research uses a Customer Loyalty Scale which consists of 4 aspects, namely making purchases regularly, buying outside the product / service line, recommending products / services to others, and not being easily influenced by the pull of competitors. The data was collected using a Likert scale with a total of 57 items. The validity values of items in this study were 0.921 and 0.929, which were measured using Cronbach's Alpha. Based on the analysis using Pearson Product Moment, it is found that there is a significant positive relationship between Customer Trust and Customer Loyalty, where rxy $=0.459$ with a significant $p=0.001<0.050$. And shows the results of the percentage analysis of $21.1 \%$. This hypothesis is stated to be accepted with the result that there is a correlation between Customer Trust and Customer Loyalty.
\end{abstract}

Keywords: Customer trust; Customer loyalty.

DOI: https://doi.org/10.51849/i-p3k.v2i1.97

Rekomendasi mensitasi :

Siregar, M. 2021, Hubungan Antara Kepercayaan Pelanggan Dengan Loyalitas Pelanggan Terhadap Online Shop. Jurnal Penelitian Pendidikan, Psikologi dan Kesehatan (J-P3K), 2 (1): 83-88. 


\section{PENDAHULUAN}

Di era serba modern dan canggih saat ini, perkembangan internet dan media sosial bukan hanya berfungsi sebagai media informasi dan media komunikasi saja tetapi juga sebagai alat untuk melakukan jual beli. Internet merupakan media elektronik yang berfungsi sebagai penunjang e-commerce (electronic commerce) dan mengalami pertumbuhan yang sangat pesat. Internet juga memberi keuntungan bagi penjual dan pelanggan, seperti pemasaran barang, makanan, minuman dan jasa melalui internet yang pada saat ini sangat efisien, praktis dan dapat menghemat waktu.

Hadirnya toko online sekarang yang memasarkan produknya melalui jaringan internet merupakan industri perdagangan yang saat ini sedang diminati oleh berbagai lapisan masyarakat termasuk mahasiswa yang gemar sekali berbelanja online. Membuka toko online sangatlah mudah, sederhana, tidak repot dan tidak membutuhkan biaya. Oleh sebab itu, toko online saat ini semakin banyak dan juga berkembang di berbagai lapisan masyarakat, pelanggan saat ini berbelanja tidak harus lagi datang ke toko dan bahkan tidak perlu lagi bertemu dengan penjual. Adapun keuntungan online shop yaitu tidak perlu lokasi yang strategis, tidak perlu toko, padat modal, sesuai kemauan, tidak perlu banyak karyawan, keuntungan lebih besar, target pasar luas dan relatif mudah. Sedangkan kelemahan online shop yaitu harus ada jaringan internet, harus mempunyai gadget seperti handphone, laptop dan sebagainya, banyak pesaing yang menjual barang yang sama, dan rawan penipuan.
Pelanggan saat ini lebih menyukai hal yang praktis dan otomatis termasuk dalam melakukan transaksi jual beli online. Pelanggan lebih mudah mencari dan memilih barang sesuai keperluannya. Online shop atau belanja online merupakan salah satu cara berbelanja yang sangat praktis. Online shop juga merupakan suatu bentuk jual beli melalui media komunikasi elektronik atau media sosial di mana pelanggan tidak perlu bersusah payah, seperti datang ke toko untuk melihat dan melakukan pembelian sesuatu yang dibutuhkan. Pelanggan merupakan tujuan akhir dari proses pembelian. Semakin sering barang yang dipasarkan maka makin meningkat Loyalitas.

Menurut Beneke (2011), Suasana, layanan dan kenyamanan menjadi pertimbangan bagi pelanggan yang berbelanja di toko, demikian juga dalam belanja online dibutuhkan adanya kenyamanan layanan, pelayanan yang baik dan mampu meningkatkan Loyalitas pelanggan. (Ayu \& Sulistyawati, 2018). Loyalitas pelanggan merupakan suatu komitmen yang mendalam untuk melakukan pembelian ulang atau berlangganan pada suatu produk atau barang secara konsisten pada masa yang akan datang. Dengan demikian, mengakibatkan pengulangan pembelian barang meskipun dipengaruhi oleh situasi dan upaya pemasaran yang mempunyai potensi untuk tidak berpindah ke toko lain (Norhermaya \& Soesanto, 2016).

Loyalitas pelanggan bukan hanya fokus pada harga tetapi juga mereka bertindak seperti pelayanan dan membantu untuk menarik pelanggan baru. Kepuasan yang dirasakan oleh pelanggan menjadi dasar dalam 
terciptanya perilaku pembelian ulang atau loyalitas pelanggan. Menurut Hill, loyalitas pelanggan merupakan perilaku yang ditunjukkan dengan pembelian rutin yang didasarkan pada pengambilan keputusan. Seorang pelanggan yang loyal adalah pelanggan yang memiliki ciri-ciri antara lain melakukan pembelian secara berulang-ulang pada toko online yang sama secara teratur, membeli lini produk dan jasa yang ditawarkan oleh badan usaha yang sama, memberitahukan kepada orang lain tentang kepuasankepuasan yang didapat, dan menunjukkan kekebalan terhadap pesaing atau toko lain.

Adapun salah satu faktor yang terbesar yang mempengaruhi loyalitas pelanggan yaitu Kepercayaan. Kepercayaan terhadap online shop adalah kepercayaan pelanggan online terhadap barang yang dijual oleh penjual online tersebut. Adanya kepercayaan akan menciptakan rasa aman dan mengurangi persepsi pelanggan akan risiko dalam pertukaran. Menurut Rofiq bahwa kepercayaan (trust) adalah kepercayaan pihak tertentu dalam melakukan hubungan transaksi berdasarkan suatu keyakinan bahwa orang yang dipercayainya tersebut memiliki segala kewajibannya secara baik sesuai yang diharapkan. (Priansa, 2018)

Dengan demikian, tanpa adanya kepercayaan pelanggan maka tidak mungkin dapat terjadi aktivitas transaksi online. Oleh sebab itu, membangun kepercayaan menjadi hal yang sangat penting dilakukan pada online shop. Dalam rangka menciptakan rasa percaya bagi pelanggan, maka penjual tidak hanya memberikan kata-kata yang menyakinkan tetapi juga penjual harus dapat memberikan kepastian barang yang di pesan oleh pelanggan sesuai dengan yang diinginkan. Dan jumlah uang yang akan di bayarkan melalui transfer bank aman dari tindakan pratik-pratik penipuan. Serta saat barang sampai ke tangan pelanggan haruslah sesuai dengan waktu yang di janjikan dan saat diterima oleh pelanggan, kemasan barang dalam kedaan baik dan sesuai dengan apa yang dipesan. Dengan adanya keberadaan online shop yang saat ini sangat digemari oleh mahasiswa dapat dibuktikan bahwa semakin tinggi kepercayaan seseorang terhadap online shop maka akan semakin sering minat berbelanja online shop maka dari itu akan mempengaruhi loyalitas pelanggan. Oleh sebab itu penulis merasa tertarik untuk melakukan sebuah penelitian tentang "Hubungan Antara Kepercayaan Pelanggan Dengan Loyalitas Pelanggan Terhadap Online Shop Pada Mahasiswa Psikologi Regular A Stambuk 2017 Universitas Medan Area".

\section{METODE PENELITIAN}

Tipe penelitian yang digunakan adalah pendekatan kuantitatif deskriptif atau korelasional dengan pola kajian korelatif dengan menempatkan variable penelitian dalam dua kelompok yaitu variabel bebas dan variabel terikat. Variabel bebas (X) Kepercayaan Pelanggan dan variabel terikat (Y) Loyalitas Pelanggan.

Kepercayaan pelanggan adalah suatu kenyakinan atau rasa percaya pelanggan terhadap sebuah toko online dengan harapan penjual menjanjikan suatu transaksi yang akan memuaskan 
pelanggan dan janji untuk mengirim barang yang disepakati ditepati.

Loyalitas pelanggan adalah suatu perilaku pembelian secara berulang-ulang atau pembelian rutin dan dengan rela akan merekomendasikan barang/jasa tersebut kepada orang lain dengan senang hati.

Penelitian ini dilakukan pada 50 orang mahasiswa Universitas Medan Area yang sering melakukan pembelian secara online shop dan dinyatakan sebagai sampel yang sesuai dengan penelitian ini. Teknik sampling yang digunakan adalah purposive sampling. Alat pengumpul data berupa skala Skala Likert. Analisis data dilakukan dengan teknik korelasi Product Moment dari Pearson menggunakan bantuan program SPSS.

\section{HASIL DAN PEMBAHASAN}

Berdasarkan hasil analisis dengan metode analisis korelasi $r$ Product Moment, diketahui bahwa ada hubungan positif antara Kepercayaan Pelanggan dengan Loyalitas Pelanggan, yaitu dengan asumsi semakin tinggi Kepercayaan Pelanggan yang dimiliki mahasiswa, maka semakin tinggi pula Loyalitas Pelanggan yang di miliki mahasiswa tersebut. Begitu pula sebaliknya, semakin rendah Kepercayaan Pelanggan yang dimiliki mahasiswa maka semakin rendah pula Loyalitas Pelanggan yang di miliki mahasiswa tersebut., dimana $r_{x y}=0,459$ dengan signifikan $\mathrm{p}=0.001<0.050$. Artinya hipotesis yang diajukan dinyatakan diterima.

Koefisien determinan $\left(\mathrm{r}^{2}\right)$ dari hubungan antara variabel bebas $\mathrm{X}$ dengan variabel terikat $\mathrm{Y}$ adalah sebesar $\mathrm{r}^{2}=$ 0.211. Ini menunjukkan bahwa Loyalitas
Pelanggan berkontribusi terhadap Kepercayaan Pelanggan sebesar 21,1\%.

Tabel. 1 Hasil Analisis Uji Hipotesis Korelasi

\begin{tabular}{lllll}
\hline Statistik & $\begin{array}{l}\text { Koefisien } \\
\text { (rxy) }\end{array}$ & $\mathrm{P}$ & $\begin{array}{l}\text { Koef. } \\
\text { Det. } \\
\text { (r2) }\end{array}$ & $\mathrm{BE \%}$ \\
\hline $\mathrm{X}-\mathrm{Y}$ & 0,459 & 0.001 & 0,211 & $21,1 \%$ \\
\hline
\end{tabular}

Hasil penelitian menunjukkan koefisien determinan $\left(\mathrm{r}^{2}\right)$ dari hubungan antara variabel bebas $\mathrm{X}$ dengan variabel terikat $Y$ adalah sebesar $r^{2}=0,211$ Ini menunjukkan bahwa Kepercayaan pelanggan berkontribusi terhadap Loyalitas pelanggan sebesar 21,1\%. Ini berarti masih terdapat $78,9 \%$ dari faktor lain terhadap Loyalitas Pelanggan, dimana faktor-faktor tersebut kepuasan pelanggan, ikatan emosi, kemudahan dan pengalaman dengan perusahaan.

Selanjutnya, untuk mengetahui Kepercayaan pelanggan dengan Loyalitas Pelanggan Pada mahasiswa, maka perlu dibandingkan antara mean/nilai rata-rata empirik dengan mean/nilai rata-rata hipotetik dengan memperhatikan besarnya bilangan SD dari masing-masing variabel. Sehingga diketahui bahwa Kepercayaan pelanggan $n$ pada mahasiswa tergolong sedang. Hal ini didasarkan pada nilai-nilai empirik yang diperoleh, yaitu sebesar 59,12 dan nilai hipotetik, yaitu sebesar 57,5 dengan selisih yang melebihi nilai SD sebesar 10,967, dan untuk Loyalitas Pelanggan tergolong sedang dengan nilai rata-rata empirik yang diperoleh yaitu sebesar 71,76 dan nilai rata-rata hipotetik, yaitu 70 dengan selisih yang melebihi nilai SD sebesar 10,688.

Hasil penelitian ini sesuai dengan fenomena yang terjadi dilapangan bahwa 
mahasiswa memiliki kepercayaan terhadap online shop sehingga adanya pembelian secara berulang-ulang yang sehingga disebut dengan loyalitas pelanggan. Bahkan para sebagian mahasiswa sudah tidak ragu lagi terhadap online shop. Hasil penelitian ini dapat dikatakan sejalan dengan teori yang menyebutkan kepercayaan merupakan salah satu faktor kunci dalam melakukan kegiatan jual beli secara online (Suhari, 2011). Menurut Hill, loyalitas pelanggan adalah perilaku yang ditunjukkan dengan pembelian rutin yang didasarkan pada pengambilan keputusan. Menurut Tjiptono, loyalitas pelanggan adalah komitmen pelanggan terhadap suatu toko berdasarkan sifat yang sangat positif dalam pembelian jangka panjang (Tugiso et al., 2016).

Salah satu faktor yang mempengaruhi loyalitas pelanggan adalah kepercayaan. Menurut Rofiq bahwa kepercayaan (trust) adalah kepercayaan pihak tertentu terhadap yang lain dalam melakukan hubungan transaksi berdasarkan suatu keyakinan bahwa orang yang dipercayainya tersebut memiliki segala kewajibannya secara baik sesuai yang diharapkan. Kepercayaan pelanggan merupakan kehendak pelanggan dalam mempercayakan sebuah perusahaan atau merek untuk menuntaskan harapannya (Gaffar, 2007).

Dengan demikian, dapat disimpulkan bahwa loyalitas pelanggan sangat dipengaruhi oleh kepercayaan. Dengan adanya kepercayaan pelanggan terhadap suatu produk/barang yang positif maka dapat berpengaruh terhadap loyalitas pelanggan. Jadi semakin tinggi kepercayaan pelanggan maka semakin tinggi pula loyalitas pada pelanggan. Pelanggan yang membeli barang secara berulang akan mengatakan hal-hal yang baik mengenai barang tersebut kepada rang lain.

\section{SIMPULAN}

Berdasarkan pada hasil yang diperoleh dalam penelitian ini, maka kesimpulan yang dapat diambil adalah sebagai berikut: Berdasarkan hasil analisis dengan metode analisis korelasi $r$ Product Moment, diketahui bahwa ada hubungan positif antara Kepercayaan dengan Loyalitas Pelanggan, yaitu dengan asumsi semakin tinggi Kepercayaan yang dimiliki mahasiswa, maka semakin tinggi pula Loyalitas Pelanggan yang di miliki mahasiswa tersebut. Begitu pula sebaliknya, semakin rendah Kepercayaan yang dimiliki mahasiswa maka semakin rendah pula Loyalitas Pelanggan yang di miliki mahasiswa tersebut, dimana $r_{x y}=$ 0,459 dengan signifikan $p=0.001<0.050$. Artinya hipotesis yang diajukan dinyatakan diterima.

Berdasarkan dari hasil Koefisien determinan $\left(\mathrm{r}^{2}\right)$ dari hubungan antara variabel bebas $X$ dengan variabel terikat $Y$ adalah sebesar $r^{2}=0.211$. Ini menunjukkan bahwa Loyalitas Pelanggan berkontribusi terhadap Kepercayaan sebesar $21,1 \%$.

Berdasarkan perbandingan kedua nilai rata-rata diatas (hipotetik dan empirik), maka dapat dinyatakan bahwa Kepercayaan tergolong sedang dengan nilai mean hipotetik sebesar 57,5 dan empirik sebesar 59,12 dan Loyalitas Pelanggan tergolong sedang dengan nilai hipotetik sebesar 70 dan empirik sebesar 


\section{DAFTAR PUSTAKA}

Arikunto, S. (2014). Prosedur Penelitian, Suatu Pendekatan Praktik. Jakarta: Rineka Cipta.

Ayu, D. P., \& Sulistyawati, E. (2018). Persepsi Nilai Pelanggan Mediasi Pegaruh Kepercayaan Merek Dan Kualitas Layanan Terhadap Loyalitas Pelaggan Berbelanja Online. Jurnal Manajemen Unud, 2353-2379.

Azwar, Saifuddin. 2014. Penyusunan Skala Psikologi. Yogyakarta: Pustaka Pelajar.

Beneke, J., Adams, E., Demetriou, O., \& Solomons, R. (2011). An exploratory study of the relationship between store image, trust, satisfaction and loyalty in a franchise setting. Southern African Business Review, 15(2), 59-74.

Ferrinadewi, E. (2008). Merek \& Psikologi Konsumen. Yogyakarta: Graha Ilmu.

Gaffar, V. (2007). Manajemen Bisnis. Bandung: Alfabeta.

Gefen, D. 2002. "Customer Loyalty in ECommerce." Journal of the Association for Information Systems Vol 3: 27-51.

Hadi, S. 2000. Statistik, Jilid II. Yogyakarta: Liberty

Hadi, S. (2015). Metodelogi Riset. Yogyakarta: Pustaka Pelajar.

Kotler \& Keller. (2006). Manajemen Pemasaran, Edisi 12 jilid 1, Terjemahan (Molan Benyamin). Indonesia: PT. Indeks.

Lepojevic, V., \& Dukic, S. (2018). Factors Affecting Customer Loyalty In The Business Market An Empirical Study In The Republic of Serbia1. Economics And Organization Vol. 15, No 3, $245-256$.

Norhermaya, Y. A., \& Soesanto, H. (2016). Analisis Pengaruh Kepuasan Pelanggan Terhadap Kepercayaan Dan Loyalitas Pelanggan Untuk Meningkatkan Minat Beli Ulang (Studi P. Diponegoro Journal of Management, Volume 5, Nomor 3, Halaman 1-13.

Nugroho, A. S. (2016). E-Commerce; Teori Dan Implementasi. Dalam B. David, Landasan Teori (Hal. 6). Yogyakarta: Ekuilibria.

Priansa, D. J. (2018). Perilaku Konsumen Dalam Bersaing Bisnis Kontemporer. Bandung: Alfabeta.

Sangadji, E. M., \& Sopiah. (2013). Perilaku Konsumen. Yogyakarta: Andi Yogyakarta.

Siregar, A. H. (2018). Pengaruh Kepercayaan (Trust) Dan Kepuasan Terhadap Loyalitas Pelanggan Online Shop (Pada Toko Jequeleen Di Kota Medan). Departemen Manajemen. Univesitas Sumatera Utara.

Siregar, S. (2017). Statistik Parametrik Untuk Penelitian Kuantitatif. Jakarta: Bumi Aksara.

Suhari, Yohannes. 2011. "Kepercayaan terhadap Internet serta Pengaruhnya pada Pencarian
Informasi dan Keinginan Membeli Secara Online." Jurnal Dinamika Informatika (Unisbank.ac.id).

Sugiyono. (2014). Metode Penelitian Manajemen. Bandung: Alfabeta.

Tugiso, I., Haryono, A. T., \& Minarsih, M. M. (Maret 2016). Pengaruh Relationship Marketing, Keamanan, Kepercayaan Dan Kualitas Pelayanan Terhadap Keputusan Pembelian Online Shop Dan Loyalitas Konsumen Sebagai Variabel Intervenin. Jurnal Managemen, Volume 2 No.2.

Yusuf, A.M. 2014. Metode Penelitian: Kuantitatif, Kualitatif \& Penelitian Gabungan. Jakarta: Kencana

Zahro, N. U., \& Prabawani, B. (2018). Pengaruh Customer Relationship Management Terhadap Loyalitas Pelanggan Tv Kabel Di Kecamatan Tembalang Melalui Kepuasan Pelanggan Sebagai Variabel Intervening (Studi Pada Pt. Mnc Sky Vision-Indovision Semarang). Jurnal Administrasi Bisnis, Volume 7, Nomor 1. 